\title{
KOMPETENCJE ZAWODOWE SĘDZIÓW A INSTYTUCJONALIZACJA PARTYCYPACJI SPOŁECZNEJ W WYMIARZE SPRAWIEDLIWOŚCI ${ }^{*}$
}

\section{WPROWADZENIE}

Przedmiotem niniejszego artykułu jest identyfikacja i analiza konceptualnej więzi między koncepcją kompetencji zawodowych sędziów a ideą upełnomocnienia władzy konstytuującej, urzeczywistniana przede wszystkim poprzez instytucje partycypacji społecznej (obywatelskiej) ${ }^{1}$. Elementy kompetencji zawodowej in genere maja status empiryczno-deskryptywny i stanowia miarodajne kryteria opisu współczesnej praktyki prawniczej ${ }^{2}$. Zostały one zrekonstruowane przez Ewę Łętowską na podstawie wieloletniej uczestniczącej obserwacji praktyki sądowego stosowania i wykładni prawa. Na wstępie należy jedynie zasygnalizować, że na kompetencję sędziego składają się trzy równoważne elementy: wrażliwość aksjologiczna, sprawność dogmatyczna oraz zaangażowanie w proces „poszukiwania prawa” (Rechtsfindung) ${ }^{3}$. W praktyce wykonywania innych zawodów prawniczych cechy te sa także pożądane. Dotychczas nie podjęto jednak filozoficznoprawnej analizy koncepcji kompetencji sędziowskich. Szczególnie interesująca wydaje się kwestia tego, czy owe kompetencje można postrzegać jako element procedury uniwersalizacji norm i refleksyjnego uzasadnienia prawa jako praktyki społecznej ${ }^{4}$.

* Dziękuję Pawłowi Skuczyńskiemu za wnikliwą lekturę, cenne uwagi i komentarze do wcześniejszych wersji tego artykułu.

${ }^{1}$ Zob. Kaleta (2018a): 41-62. Należy przy tym podkreślić, że niniejszy artykuł koncentruje się niemal wyłącznie na analizie kompetencji sędziów. Wiele uwag sformułowanych w tym kontekście może budzić istotne wątpliwości w odniesieniu do innych zawodów prawniczych. Natomiast termin „koncepcja” jest stosowany ze świadomościa, że mówimy raczej o określonym projekcie $\mathrm{w}$ fazie badawczej, wymagającym głębszego przemyślenia niż o koncepcji w tradycyjnym rozumieniu tego słowa. Ukształtowanie adekwatnego, nieintuicyjnego sposobu użycia wyrażenia „koncepcja kompetencji” wymaga dalszych, szczegółowych badań.

${ }^{2}$ Przyjmujemy przy tym konsekwentnie, że współcześnie praktyka prawnicza opiera się na dwóch podstawach: przepisach prawnych i wyprowadzanych z nich normach-regułach prawnych oraz na standardach ukształtowanych na tle przepisów lub niezależnie od nich. Standardy prawne to uogólnione wzorce postępowania dotyczace sposobu traktowania obywateli przez władze publiczne, odzwierciedlające usprawiedliwione oczekiwania w zakresie rzetelności prawa i praktyki jego stosowania.

${ }^{3}$ Łętowska (2003): 30-31.

${ }^{4}$ Przyjęcie koncepcji „triady” kompetencyjnej nie wyklucza twierdzenia, że istnieją jeszcze inne istotne cechy i ujęcia badanego fenomenu, zob. np. Zienkiewicz (2018): 94-102. 
Niniejszy artykuł ma na celu doprecyzowanie i rozwinięcie koncepcji „triady" kompetencyjnej w świetle założeń określających całościową wizję porządku demokratycznego. Owa wizja zasadza się na założeniu, że w XXI w. społeczna legitymizacja władzy sądowniczej jest w coraz większym stopniu wynikiem oceny jakości procesu podejmowania decyzji ${ }^{5}$. Osią rozważań uczyniono założenie, że standardy jakości rządzenia stanowią łącznik między refleksyjnym konstytucjonalizmem, responsywnym wymiarem sprawiedliwości i demokracja partycypacyjną (resp. deliberatywna $)^{6}$. Punktem wspólnym tych sfer jest racjonalność komunikacyjna ujmowana jako podstawa legitymizacji działań władz publicznych w społeczeństwie sieciowym.

Próba realizacji celu badawczego zostanie przy tym oparta na dwóch krokach. W pierwszym kroku należy w szczególności określić status kompetencji zawodowych na gruncie filozofii praktycznej przez zakwalifikowanie ich do określonej sfery standardów praktycznego myślenia (pragmatyczności, etyczności bądź moralności). W drugim kroku trzeba pochylić się nad problemem recepcji teorii kompetencji (zdolności) na gruncie teorii demokracji deliberatywnej ${ }^{7}$. Mając na uwadze powyższe, artykuł podzielono na dwie części: teoretycznoprawną (opisowo-analityczna) i filozoficznoprawną (normatywna). W pierwszej części zostaną przedstawione poszczególne elementy „triady" kompetencyjnej sędziego w celu wykazania, że refleksyjne kształtowanie kompetencji stanowi warunek pełnego uczestniczenia w praktyce prawniczej. W drugiej części artykułu zostanie poddana weryfikacji teza, że instytucje demokracji partycypacyjnej tworzą optymalne warunki do wykorzystania kompetencji sędziowskich w procesach upełnomocnienia obywateli. W badaniu zostanie wykorzystana metoda analizy rekonstrukcyjno-krytycznej.

\section{II. „TRIADA” KOMPETENCYJNA SĘDZIEGO JAKO STANDARD OPISU PRAKTYKI PRAWNICZEJ}

Teorie kompetencji zawodowych stanowią alternatywę dla teorii cnót zawodowych w obliczu fragmentaryzacji wspólnot, niestabilności struktur społecznych i obniżenia zaufania społecznego. Przedmiotem teorii kompetencji

\footnotetext{
${ }^{5}$ Burdziej (2017): 8.

${ }^{6}$ Wskazuje się, że koncepcje demokracji partycypacyjnej i demokracji deliberatywnej posiadają inne uzasadnienie, zob. Juchacz (2006). Deliberacja jest jednym ze sposobów realizacji idei partycypacji. Demokracja partycypacyjna ma przy tym charakter subsydiarny względem demokracji przedstawicielskiej i jest urzeczywistniana przede wszystkim w kontekście pozawyborczym. Koncepcje demokracji partycypacyjnej i deliberatywnej utożsamia ze sobą m.in. Izdebski (2012): 63. Natomiast Janusz Grygieńc wskazuje, że idee partycypacji i deliberacji nie są ze sobą spójne, a ich pogodzenie jest możliwe wyłącznie na poziomie lokalnym, zob. Grygieńć (2016): 75-94. Trzeba przy tym zasygnalizować, że obecnie na gruncie teorii demokracji coraz szerszą akceptacje zyskują koncepcje formalne i deliberatywne, zob. Kaleta (2018b): 16-20.

${ }^{7}$ Perspektywa zdolności (capability/capabilities approach) została rozwinięta przez Amartyię Kumar Sena i Marthę Craven Nussbaum, zob. Sen (1985); Nussbaum (2011). W niniejszym artykule przyjęto, że kompetencje prawnicze stanowią szczególną postać zdolności nawiązująca do sfery wykonawstwa zawodowego.
} 
jest doskonalenie praktyki jako działania zespołowego, na którego jakość maja wpływ poszczególni uczestnicy (aktorzy), działający w warunkach ograniczonej racjonalności (bounded rationality). Nie mamy przy tym na myśli kompetencji w znaczeniu treściowym (power), a więc uprawnienia do działania. W piśmiennictwie coraz silniej podkreśla się znaczenie „miękkich” umiejętności prawników, w tym: inteligencji emocjonalnej (mindfulness), wielozadaniowości (multitasking) i udatności działania (skilfulness). W niniejszym artykule przyjmujemy zatem interpretację kompetencji oparta na intuicjach znaczeniowych, takich jak: zdolność (capability), potencjał (capacity), umiejętność (skill), możliwość działania (ability), zmysł praktyczny (habitus) lub trwała dyspozycja (hexis). W takim ujęciu na plan pierwszy wysuwa się relacja profesjonalisty z kontekstem poznawczym. Natomiast przez kompetencje zawodowe rozumie się szczególnego rodzaju standardy poznawcze, umiejętności heurystyczne lub modalności percepcyjne ujawniające się na najbardziej podstawowym (tj. zmysłowym) poziomie poznania. Maja one charakter imperatywów hipotetycznych, stanowią wytwór tradycji i kultury prawnej, które należą do płaszczyzny etyczności ${ }^{8}$. Kompetencje zawodowe pełnią rolę pomocniczą względem standardów deontologicznych wywodzacych się ze sfery pragmatyczności ${ }^{9}$. Dlatego można argumentować, że zgłaszają roszczenie do uzasadnienia z punktu widzenia moralności ${ }^{10}$. Problem ten zostanie jeszcze poruszony w drugiej części niniejszego artykułu.

Jak już wspomniano, na tzw. triadę kompetencyjną sędziego składają się następujace elementy: wyczucie aksjologiczne (dostrzeganie problemów aksjologicznych), sprawność dogmatyczna, zwana interpretacyjną lub funkcjonalna (prawnicze know-how niezbędne w działaniu, w tym: umiejętności metodyczne, warsztat teoretyczny, sztuka uzasadniania sytuacyjnych ocen) oraz zaangażowanie (przełamywanie oportunizmu, samodzielność myślenia, moralna odwaga i determinacja w obronie własnej wizji interpretacyjnej wynikającej z rzemiosła prawniczego).

Ta ostatnia cecha zbliża prawo do sztuk performatywnych, ponieważ wskazuje na związek między konstruującą funkcją języka prawniczego (argumentacyjną warstwą wypowiedzi prawnej) a działaniem za pomocą słów (etyka dyskursu i interpretacji, władzą nad znaczeniem prawa), społeczną legitymizacją praktyki i moralną odpowiedzialnością. Ostateczny kształt rozstrzygnięcia prawnego jest zatem wypadkową wielu różnorodnych czynników. Refleksyjne kształtowanie „triady” kompetencyjnej (,widzieć - wiedzieć - chcieć”) wymaga nieformalistycznego myślenia o prawie w kategoriach standardów, a nie ścisłych norm-reguł.

Sędziowska „triada” kompetencyjna obrazuje mechanizm powstawania i artykułowania wątpliwości interpretacyjnych (deficytu aksjologicznego). Jest ona niezbędna dla identyfikacji normy jednostkowego zastosowania będącej prawem (standardem) dla konkretnego rozstrzygnięcia, przy czym każda in-

\footnotetext{
8 Por. Habermas (2005): 175-176.

9 Por. Habermas (2005): 174-175.

10 Por. Habermas (2005): 174-177.
} 
terpretacja pozostaje nierutynowa i niepowtarzalna ${ }^{11}$. W dalszej kolejności skupimy się na szczegółowej analizie poszczególnych elementów kompetencji sędziowskiej w celu wykazania, że relacja między prawnikami a obywatelami jest zapośredniczona przez interpretację rozumianą jako refleksyjna praktyka umożliwiająca integrowanie prawa z normatywnościami społecznymi.

Pierwszym elementem „triady” kompetencyjnej sędziego jest wrażliwość aksjologiczna rozumiana jako zdolność umożliwiająca nasycanie prawa aksjologia. Owa wrażliwość jest zdeterminowana przez koncepcję prawa przyjęta przez danego prawnika i standardy etyki zawodowej. Jej istota jest baczenie na wartości konstytucyjne i prawnomiędzynarodowe w codziennej praktyce. Ważnym składnikiem wrażliwości aksjologicznej są także standardy rozumności, roztropności czy „zdrowego” rozsądku oraz intuicje w rozumieniu psychologii moralności i nauk kognitywnych. Pełnią one istotną rolę m.in. w dokonywaniu ocen moralnych. Możliwe staje się włączanie nowych kategorii poznawczych do analizy procesów praktycznego myślenia prawników ${ }^{12}$.

Drugim elementem „triady” kompetencyjnej sędziego jest sprawność zawodowa, czyli biegłość w sztuce, technikach interpretacji prawa i metodach jego poznawania. Kompetencja ta obejmuje prawnicze prawidła zręczności. Wyraża się ona w umiejętności przekładania aksjologii konstytucyjnej na instytucje, konstrukcje, rozumowania i wnioskowania. Sprawność interpretacyjna znajduje odzwierciedlenie przede wszystkim w uzasadnieniu orzeczeń sądowych. Należy przy tym zaznaczyć, że orzeczenia wydane w granicach swobodnego uznania różnią się od innych rozstrzygnięć tym, że decyzje podejmowane zgodnie $\mathrm{z}$ metodami wykładni pozajęzykowej w toku konstruowania założeń aksjologicznych modyfikujących ustawowe normy dystrybucji dóbr muszą być lepiej uzasadnione i poparte rzetelnymi, przejrzystymi argumentami oraz zwięzłą prezentacją alternatywnych wariantów interpretacji ${ }^{13}$.

Jak wskazuje Łętowska, ,interpretacja skuteczna to interpretacja starająca się o własną legitymizację. Tej zaś nie ma bez próby perswazji i dialogu"14. Interpretacja prawa jest wszakże kwestia przekonywania za pomoca racji (imperio rationis $)^{15}$. Natomiast uzasadnienie sądowe stanowi środek komunikacji, za pomocą którego prawnik prezentuje kunszt wykładniczy i legitymizuje społecznie swoją decyzję. Pozwala ono redukować ryzyko arbitralności rozstrzygnięć, zapobiegać wywołaniu społecznego poczucia deficytu sprawiedliwości oraz sprzyja egzekwowaniu obliczalności czy rozliczalności (accountability) decyzji sądów.

Wskazane wydaje się także krytyczne i sceptyczne podejście sądów najwyższych instancji i trybunałów do stosowania tzw. argumentu z własnego autorytetu. Argument ten, podobnie jak odwoływanie się organu orzekającego do figury retorycznej racjonalnego prawodawcy, ma często na celu ukrycie wątpliwości interpretacyjnych (aksjologicznych) prawnika i może stanowić

\footnotetext{
11 Łętowska (2003): 27.

12 Zob. np. Wojtczak (2017).

13 Smolak (2007): 32.

14 Łętowska (2002): 37.

15 Łętowska (2003): 35.
} 
przejaw niestaranności argumentacyjnej. W sytuacji niewystępowania relacji deontycznej (podporządkowania) winien być on traktowany subsydiarnie, a nie jako kluczowy w danej kwestii ${ }^{16}$.

Sądy najwyższych instancji oraz sądy konstytucyjne (,sądy od prawa, a nie od faktów”) kształtują poglądy prawne sądów niższych instancji i organów pomocniczych wymiaru sprawiedliwości (np. komorników sądowych) oraz oddziałują na metodykę pracy i strategie działania profesjonalnych pełnomocników (adwokatów i radców prawnych). Sądy niższych instancji są zasadniczo związane wykładnią prawa przedstawioną przez Trybunał Konstytucyjny, Sąd Najwyższy czy Naczelny Sąd Administracyjny. Sądy najwyższych instancji obowiązuje zatem podwyższony standard staranności argumentacyjnej. $\mathrm{W}$ świetle tego podejścia stosowanie argumentu z autorytetu obniża jakość dialogu sądowego i jest rodzajem kuglarstwa interpretacyjnego, w myśl paremii apices iuris non sunt iura.

Trzecim elementem „triady” kompetencyjnej sędziego jest zaangażowanie w „walkę o wykładnię” i poszukiwanie udatnego rozwiązania problemu aksjologicznego. Istotą zaangażowania jest kwestionowanie sposobów rozumowania leżących u podstaw dotychczasowej praktyki interpretacyjnej. W praktyce okazuje się często, że rozwiązań problemów prawnych trzeba poszukiwać metodą myślenia indukcyjnego (,od kazusów do norm i problemów systemowych"), w myśl maksymy da mihi factum dabo tibi ius. Zaangażowanie wymaga umiejętności wyważania racji, otwartości, empatii, receptywności na argumenty stron i gotowości do ciagłej nauki ${ }^{17}$.

Aby lepiej zrozumieć istotę zaangażowania, należy zwrócić uwagę na jego związek ze sprawnością interpretacyjną. Istotą tej ostatniej jest interpretacyjny (,miękki”) aktywizm, przez który należy rozumieć umiejętność aktywnego dostrzegania relewantnych wykładników interpretacyjnych. Pamiętać przy tym należy, że w środowisku prawniczym w istotnej mierze akceptowana jest zasada in dubio contra iudici activitatem, zgodnie z którą aktywizm sędziowski jest niedopuszczalny, nieprzekraczalna granicę interpretacji stanowi znaczenie językowe tekstu prawnego, wykładnia pozajęzykowa zaś ma charakter jedynie subsydiarny ${ }^{18}$.

Natomiast interpretacyjny aktywizm nie jest wkraczaniem w sferę zastrzeżoną dla ustawodawcy, lecz stanowi wyraz rozsądnej niezgody i aksjologicznego sprzeciwu (np. sędziego w ramach składu orzekającego) wobec dotychczasowej praktyki wykładniczej. Jest on uruchamiany in casu w celu zasygnalizowania błędów systemowych, realizacji wymogu sprawiedliwości oraz standardu skutecznej i realnej ochrony sądowej. Współcześnie dobór metod wykładni kształtuje się sytuacyjnie i jest uzależniony od okoliczności danego przypadku. Nie ulega przy tym wątpliwości, że wykładnia „scalająca" (realizacja zasady effet utile) jest obowiąziem interpretacyjnym sędziego orzekającego w sprawach z tzw. elementem unijnym. Aktywizm interpreta-

\footnotetext{
16 Romanowicz (2014): 515.

17 Koncewicz (2016): 208.

18 Por. wyrok SN z 12 czerwca 2015 r., II CSK 518/14, Lex nr 1754050.
} 
cyjny jest niezbędny m.in. w procesie kształtowania polityki praw człowieka, realizacji naprawczej funkcji wykładni oraz w praktyce horyzontalnego stosowania praw podstawowych i rozproszonej sądowej kontroli konstytucyjności prawa. Nieprzekraczalne granice aktywizmu sędziowskiego wyznaczają przy tym pozostałe elementy „triady” kompetencyjnej, konstytucyjna zasada proporcjonalności i zasada moralnej odpowiedzialności.

„Triada” kompetencyjna sędziego stanowi korekturę i obiektywne kryterium oceny praktyki prawniczej. Cechą współczesnego prawa jest zaś dynamizm ontologiczny. Podejście to znajduje oparcie w koncepcji procesualnej ontologii społecznej ${ }^{19}$. W jej świetle praktyka jest postrzegana jako motywowana wartościami (ideałami) aktywność, która zmierzać ma do takiej przebudowy relacji społecznych, by odzwierciedlały się w nich ludzkie interakcje, przyczyniając się w ten sposób do doskonalenia autonomii jednostek ${ }^{20}$. W takim ujęciu prawo jest jednocześnie porządkiem zinstytucjonalizowanym i instytucjonalizującym się. Ontologicznie ugruntowana koncepcja kompetencji sędziowskich stanowi punkt odniesienia rozważań nad rolą standardów partycypacji w praktyce prawniczej.

\section{PARTYCYPACJA DELIBERATYWNA JAKO NORMATYWNY STANDARD PRAKTYKI SĄDOWEGO STOSOWANIA PRAWA}

Współcześnie wiele uwagi poświęca się partycypacji społecznej w tworzeniu prawa czy $\mathrm{w}$ samorządzie terytorialnym. W piśmiennictwie dostrzega się, że konieczne jest uzupełnienie systemu władztwa publicznego o rozmaite środki demokracji bezpośredniej i semiimperatywnej ${ }^{21}$. Idee partycypacji przenikają również do refleksji dotyczącej sądowego stosowania prawa. Relacja między władzą sądowniczą a władzą konstytuująca jest przy tym jednym z centralnych zagadnień współczesnej filozofii prawa. Wzrost znaczenia rozwiązań prawno-instytucjonalnych uwzględniających idee partycypacji i deliberacji w owej relacji stanowi tendencję ogólnoświatowa, wynik zmian w sferze społecznych ocen, oczekiwań legitymizacyjnych oraz form aktywności obywatelskiej, które nastapiły w ciągu ostatnich kilkunastu lat. W wielopłaszczyznowym systemie prawa do funkcji sądów należy już nie tylko rozstrzyganie konfliktów, ale również współkształtowanie określonych polityk publicznych (policies), w szczególności polityki ochrony praw człowieka. Jednym z przejawów tego zjawiska jest tzw. usądowienie władzy, w tym judycjalizacja (judykalizacja) polityk ${ }^{22}$. W tym kontekście celem partycypacji społecznej jest kształtowanie dodatkowych kanałów komunikacji między sądami a interesariuszami wymiaru sprawiedliwości.

\footnotetext{
${ }^{19}$ Zob. Renault (2016): 17-32.

${ }^{20}$ Zob. Koczanowicz (2011): 106.

${ }^{21}$ Uziębło (2009): 19.

${ }^{22}$ Skrzypiński (2014): 53-64.
} 
W obliczu powyższych zjawisk zmienia się także sposób postrzegania praw podmiotowych. Według teoretyków refleksyjnego konstytucjonalizmu, takich jak Neil Walker, Martin Loughlin czy Hans Lindahl, prawa podmiotowe stanowią nie tylko „karty atutowe” i środki ochrony konstytucyjnych wartości, które władze publiczne winny „brać poważnie” (respektować), ale także narzędzie upełnomocnienia jednostek w procesie stosowania prawa. Istota upełnomocnienia (w sensie empowerment) jest samokonstytucjonalizacja, czyli refleksyjna transformacja uzasadnionych i słusznych racji w wiążące standardy ${ }^{23}$.

Legitymizacja współczesnego sądownictwa ma przy tym charakter funkcjonalny i opiera się na idei responsywności (reagowania na oczekiwania społeczne). Koncepcja legitymizacji poprzez jakość procedur (throughput legitimacy) przełamuje napięcie między legitymizacją wkładowa - input (kładącą nacisk na reprezentację interesów) a legitymizacją wynikową - output (zorientowaną na efektywność ochrony wartości konstytucyjnych). W takim ujęciu uwyraźnia się zależność między partycypacją społeczną a sędziowska efektywnością we wpływaniu na praktykę konstytucyjna. Partycypacyjna legitymacja prawa może być postrzegana jako alternatywa dla głównych modeli uprawomocnienia (pozytywistycznego, prawno-naturalnego) bądź też jako uzupełnienie modelu deliberatywnego ${ }^{24}$.

Koncepcja demokracji partycypacyjnej zasadza się na idei rozwijania społecznych i politycznych zdolności obywateli w konkretnych procedurach policy making ${ }^{25}$. Możliwe staje się urzeczywistnianie edukacyjnego wymiaru partycypacji i postulatu uspołecznienia struktur decyzyjnych, również w perspektywie transnarodowej ${ }^{26}$. Wskazuje się przy tym, że sztuka czynienia sprawiedliwości obejmuje wypracowywanie standardów, takich jak: nadrzędność konstytucji, podział władz, niezawisłość sędziów, niezależność sądów, rozbudowany system organów kontroli przestrzegania prawa, w tym sądownictwa administracyjnego, odpowiedzialność państwa za szkody wyrządzone obywatelom przez działanie niezgodne z prawem oraz konstytucyjne gwarancje podstawowych praw i wolności ${ }^{27}$. Standardy te determinuja granice władzy konstytuującej i są niezbędne dla urzeczywistniania zasad dobrego rządzenia (good governance), w tym zasady partycypacji.

Towarzyszace partycypacji zjawisko orkiestracji (instrumentacji) działań aktorów wyzwala potencjał struktur oddolnych typu grassroots movements. W takim ujęciu władze publiczne, w tym judykatywa, pełnią bardziej funkcję integratora działań w sieciach niż aktora dominującego w imperatywnych procesach decyzyjnych.

${ }^{23}$ Zob. Kaleta (2018a): 55.

${ }^{24}$ Należy przy tym zwrócić uwagę na mankamenty rozwiązań deliberatywnych, w tym tzw. decyzyjny paradoks deliberacji. Wyraża się on m.in. w napięciu między zasadą konsensu a głosem mniejszości (podmiotów wykluczonych lub niezainteresowanych) i ukrytym dążeniem do dominacji na płaszczyznach: relacyjnej, strukturalnej i systemowej. Krytycy podnoszą, że nie ma prostej zależności między istnieniem debaty a trafnością wyboru lub decyzji. Zob. Zabdyr-Jamróz (2014): 89-102 oraz Azmanova (2018): 68-78.

25 Pateman (1970): 43.

${ }_{26}$ Pateman (1970): 44-45.

27 Izdebski (2001): 30. 
W celu określenia roli partycypacji społecznej w praktyce sądowego stosowania prawa analizowanej przez pryzmat koncepcji kompetencji sędziowskich za punkt wyjścia dalszych rozważań należy przyjąć perspektywę praw podmiotowych ujmowanych jako rdzeń konstytucjonalizmu. W literaturze wskazuje się, że prawa podmiotowe mogą mieć charakter negatywny (defensywny), pozytywno-prestacyjny (społeczno-służebny) lub pozytywno-partycypacyjny (wprost związany z demokracja ${ }^{28}$. Typologia ta ukazuje kompleksowe ujęcie praw podmiotowych, ponieważ odwołuje się do kryterium relacyjnego - pozycji prawnej jednostki we wspólnocie.

Prawa trzeciej generacji o charakterze pozytywno-partycypacyjnym (np. do dobrej demokracji, do dobrych polityk publicznych, do dobrego rzadzenia, do dobrej administracji) nie mogą być podstawą skonkretyzowanego roszczenia publicznoprawnego. Obowiązek ich ochrony wynika z postępu cywilizacyjnego. Zbiorowy wymiar praw trzeciej generacji, nazywanych niekiedy prawami solidarnościowymi, wyraża się $\mathrm{w}$ tym, że pełnią one funkcję wspierająca wobec indywidualnych praw i wolności. Dynamiczny rozwój praw trzeciej generacji należy postrzegać jako wynik tzw. rewolucji praw począwszy od drugiej połowy XX w. Efektem tej rewolucji jest standard „rzadów praw człowieka”. Treść praw pozytywno-partycypacyjnych kształtuje się sytuacyjnie w dyskursie orzeczniczym (poprzez akty osądu), a ich ochrona polega m.in. na stosowaniu wykładni prokonstytucyjnej, uwzględnianiu standardów typu soft law jako argumentu walidacyjnego oraz refleksyjnym moderowaniu dyskursu praw człowieka przez sądy w tych kategoriach spraw lub postępowań wielopodmiotowych, w których konieczne jest angażowanie wszystkich interesariuszy oraz uzgadnianie interesu prywatnego (jednostki) z interesem publicznym (wspólnoty) ${ }^{29}$.

Należy przy tym zaakcentować, że perspektywa kompetencji, rozumianych jako podstawowe zdolności uczestników dyskursu, została najszerzej recypowana na gruncie teorii demokracji deliberatywnej. Zdolności są niezbędnym aspektem postawy deliberatywnej i wskazuja na wstępne warunki pełnej realizacji prawa głosu (partycypacji) w debacie publicznej ${ }^{30}$. Dlatego to właśnie na gruncie teorii demokracji deliberatywnej należy poszukiwać filozoficznoprawnego uzasadnienia związku między kompetencjami zawodowymi sędziów a idea partycypacji społecznej ${ }^{31}$.

Zdaniem Rainera Forsta - przedstawiciela trzeciego pokolenia szkoły frankfurckiej - demokracja stanowi polityczną formę sprawiedliwości ${ }^{32}$. Nato-

${ }^{28}$ Izdebski (2006): 149-150.

${ }^{29}$ Napięcie między jednostką a wspólnota jest inherentną właściwością demokracji.

${ }^{30}$ Nussbaum (2011): 33-35, 180.

31 Zob. Cohen (1989): 17-34; Benhabib (2011); Mansbridge (2018). Z uwagi na ograniczone ramy artykułu nie jest możliwe omówienie problemu recepcji teorii kompetencji w ramach poszczególnych faz rozwojowych teorii demokracji deliberatywnej (epistemiczno-proceduralnej, instytucjonalno-praktycznej i systemowej). Zob. Juchacz (2015). Nie ulega jednak wątpliwości, że koncepcje demokracji deliberatywnej opierają się na wspólnym założeniu, że konieczne jest zredefiniowanie roli prawników w społeczeństwie w celu wyeliminowania rozłamu między obywatelami a prawem rozumianym jako praktyka społeczna.

${ }^{32}$ Forst (2017a): 239. 
miast idea regulatywną demokracji deliberatywnej jest zasada uzasadniania (the principle of justification) pozyskana metoda rekursywnej rekonstrukcji (hermeneutycznej rekursji) z roszczeń ważnościowych ${ }^{33}$. Normatywność norm społecznych (np. prawnych) ma przy tym inny status niż normatywność fundamentalnych zasad praktycznego rozumu (zasady uzasadniania i zasady odpowiedzialności) identyfikowanych na postkonwencjonalnym poziomie indywidualnego rozwoju moralnego. Normatywności te sa rozpoznawane przy pomocy kompetencji refleksyjnych obywateli - odpowiednio wglądu praktycznego pierwszego stopnia (first-order practical insight) i wglądu praktycznego drugiego stopnia (second-order practical insight) jako elementu ścisłej refleksji ${ }^{34}$. Natomiast $\mathrm{u}$ podstaw demokracji deliberatywnej opartej na kulturze uzasadniania stoi władza noumenalna (noumenal power), przez która należy rozumieć dążenie do posługiwania się racjami (reasons) ${ }^{35}$. Racje są zaś zawsze powiązane $\mathrm{z}$ wymogiem refleksyjnego uzasadnienia norm rekonstruowanych $\mathrm{w}$ procedurach argumentacyjnych prowadzonych zgodnie z zasadami etyki dyskursu. Zasada uzasadniania implikuje wymogi wzajemności (reciprocity) i generalności (generality) ${ }^{36}$. Racje uzasadniające decyzje dotyczące norm powinny pozytywnie przejść tzw. test rozsądnego sceptyka ${ }^{37}$, ergo nie mogą być odrzucone z punktu widzenia wyżej wskazanych wymogów. Zasadzie uzasadnienia odpowiada prawo do uzasadnienia (the right to justification), które ma status prawa drugiego stopnia (metaprawa). Prawo to stanowi podstawę relacji moralnej, która implikuje - w sensie nieinstrumentalnym - bezwarunkowy obowiązek uzasadnienia oraz prawo obywateli do wolnej i równej partycypacji w dyskursie dotyczacym norm. W takim ujęciu autonomia ma charakter antypaternalistyczny ${ }^{38}$. Prawa podmiotowe stanowia instytucje i kategorie polityczne, które obywatele mogą wykorzystywać jako środki praktycznej weryfikacji równości. Ta ostatnia jest zarazem pierwszym wymogiem konstruktywistycznie pojętej sprawiedliwości ${ }^{39}$.

W świetle przedstawionych założeń istota deliberatywnej partycypacji $\mathrm{w}$ procesie formułowania racji uzasadniających decyzje prawne i cele integrujace praktyki społeczne jest kompetentne uczestnictwo interesariuszy. Urzeczywistnianie standardów sprawiedliwości, w rozumieniu jak powyżej, wymaga więc zintegrowania kompetencji sędziów z kompetencjami publicznymi obywateli ${ }^{40}$. Jest to możliwe m.in. dzięki odpowiedniej komunikacji na sali sądowej i refleksyjnemu modelowaniu dystansu władzy przez sędziów. Należy przy tym zwrócić uwagę na następujący problem. Z jednej strony można argumentować, że zróżnicowanie poziomu uczestnictwa ze względu na kryterium kompetencyjne nie prowadzi do wykluczenia określonych podmiotów z dyskur-

\footnotetext{
33 Zob. Forst (2011), (2013), (2017b).

${ }^{34}$ Forst (2011): 57.

35 Forst (2017b): 40.

36 Forst (2011): 6.

37 Por. Smolak (2019): 30-35.

38 Forst (2011): 125.

39 Forst (2017b): 43.

${ }^{40}$ Cern (2014): 57-68.
} 
su prawnego, lecz polega na dążeniu zarówno profesjonalistów, jak i obywateli (laików) do jak najlepszego uzasadnienia formułowanych racji. Z drugiej zaś strony trzeba zauważyć, że napięcie między władczym (eksperckim) charakterem praktyki orzeczniczej a ideą deliberacji ma charakter nieusuwalny. Uczynienie sądów instytucjami deliberującymi umożliwia co najwyżej wzmocnienie ich publicznej legitymizacji, lecz nie zapewnia sędziom demokratycznego mandatu ani nie rozwiąuje kwestii uprzywilejowania instytucjonalnego prawników w dyskursie prawnym. Jest to fundamentalny problem filozoficznoprawny, który rzecz jasna nie może być jednoznacznie rozstrzygnięty.

Można jednak rozsądnie argumentować, że kompetencje sędziowskie sa praktycznymi zdolnościami, które służą realizacji prawa do uzasadnienia jako elementu prawa do sądu. Co więcej, współcześnie istotnym aspektem legitymizacji sądownictwa jest aktywizm poznawczy rozumiany jako kognitywne zaangażowanie sędziego realizowane przez prawo do wysłuchania ${ }^{41}$. To ostatnie stanowi praktyczną implikację prawa do uzasadnienia. Efekt legitymizacji decyzji uzyskuje się więc przez położenie akcentu na obowiązek słuchania. Idea partycypacji deliberatywnej w sądownictwie realizowana jest przy tym m.in. za pośrednictwem tzw. instytucji pomostowych. Instytucje te umożliwiają integrowanie praktyki orzeczniczej z normatywnością społeczną przez dokapitalizowanie wiedzą. Tytułem przykładu należy wskazać: udział czynnika społecznego w wymiarze sprawiedliwości (instytucję sędziów społecznych ławników), współpracę organizacji pozarządowych z wymiarem sprawiedliwości (np. centra sprawiedliwości naprawczej, obywatelski monitoring sądów, instytucje typu amicus curiae, sieci sądowe, dyskursywnie zaprojektowane konsultacje obywatelskie) i refleksyjne uzasadnienie sądowe. Instytucje pomostowe pozostaja jednocześnie wewnątrz i na zewnątrz praktyki orzeczni$\mathrm{czej}^{42}$. Możliwe jest więc poszerzenie sposobu rozumienia partycypacji społecznej przez przyznanie jej statusu standardu prawnego.

W takim ujęciu fundamentem ochrony praw pozytywno-partycypacyjnych jest dialog sądowy. Ów dialog wymaga wypracowania pluralistycznego podejścia do rozstrzygania kolizji między wartościami oraz opanowania metodyki budowania optymalnych kombinacji norm w polu określonym przez minimalne standardy (warunki brzegowe) niezbędne dla przetrwania wieloskładnikowego systemu prawa. Refleksyjne kształtowanie kompetencji sędziowskich umożliwia przy tym poszukiwanie racji uzasadniających rozstrzygnięcie w sferze normatywności społecznej. Obywatele najpełniej partycypuja w procesach decydowania prawnego, gdy ich racje zostają rzeczywiście wysłuchane i odzwierciedlone w motywach ustnych oraz w pisemnym uzasadnieniu rozstrzygnięcia. Kognitywny charakter prawniczego zaangażowania wyraża się zaś w tym, że w procesie „poszukiwania prawa” ekspercki podział ról ulega transgresji, a więc zawieszona zostaje relacja nierównorzędności generowana przez funkcjonalny podział pracy i sam język kompetencji zawodowych. Więź między prawnikami a obywatelami reprodukowana jest $\mathrm{w}$ planie hory-

${ }^{41}$ Skuczyński (2019): 365-366.

${ }^{42}$ Bańkowski (2009): 186. 
zontalnym (między równymi). Jej osnowę stanowi uznanie równości w człowieczeństwie i idea poszanowania godności proceduralnej. W polskim wymiarze sprawiedliwości wyraźnie dostrzegalny jest jednak deficyt mechanizmów komunikacyjnych, a postulaty dyskursywno-dialogicznego kształtowania procesów decyzyjnych traktowane są z dystansem. Stanowi to istotną przeszkodę w działaniach upełnomocniajacych.

Wizja prawa łącząca kompetencje sędziowskie z ideami partycypacji i dialogu musi być przy tym ograniczona przez mechanizmy krytyki społecznej, które służą ochronie instytucji przed zakusami populizmu i weryfikacji intencji uczestników dyskursu. Mechanizmy te określamy mianem etyki demokracji ${ }^{43}$. Ta ostatnia stanowi dziedzinę filozofii społecznej obejmującą zbiór aksjonormatywnych założeń dotyczących społecznego ustalania i regulowania tego, co indywidualne. Koncepcja etyki demokracji umożliwia interpretację i krytykę ideałów instytucjonalnych rekonstruowanych z praktyk.

Centralnym założeniem etyki demokracji jest wspólnota krytyczna rozumiana jako sposób postrzegania rzeczywistości społecznej ukierunkowany na tworzenie alternatywnych wzorców instytucjonalnych przez ustawiczna pracę wyobraźni demokratycznej. Dzięki pracy wyobrażeniowej możliwe jest właczenie autonomii jednostki w kontekst społeczny. Kluczowe znaczenie dla kształtowania wyobraźni jako środka oceny reguł ma refleksyjna (resp. estetyczna) władza sądzenia. W takim ujęciu źródłem powinności jest wartościowanie faktów dokonujące się dyskursywnie w sferze kultury rozumianej jako intersubiektywny porządek wyobrażony. Wyobraźnia stanowi formę świadomości krytycznej, za pomoca której ludzie konceptualizują swoje wybory i decyzje. Zakłada ona nie tylko przewidywanie konsekwencji własnego działania, zgodnie z zasadą quidquid agis, prudenter agas et respice finem, ale musi być również sprzężona z pozytywną odpowiedzialnością. Ta ostatnia stanowi zarazem zasadę moralna, kategorię ontologiczną i formę oporu jednostki wobec populistycznych praktyk lub ideałów. Populizm jest wszakże kluczowym zagrożeniem wynikającym ze wspólnoty. Zagrożenie to jest wpisane w istotę demokracji. Powiązanie moralnej odpowiedzialności prawników z wyobraźnią konstytucyjna jest niezbędne dla tworzenia kontekstu świadomego zaangażowania w promocję standardów praworządności.

Refleksyjne kształtowanie kompetencji sędziowskich jest przy tym ważne dla praktycznej realizacji ideału wspólnoty inkluzyjnej leżącego u podstaw demokracji partycypacyjnej. Należy jednak zaznaczyć, że partycypacyjna wizja stosunków prawnych daje się utrzymać tylko w warunkach silnego społeczeństwa obywatelskiego i kultury praworządności. W Polsce istnieje deficyt regulacji prawnych wspomagających tworzenie i wdrażanie instytucji partycypacji społecznej. Zachowujac poczucie realizmu wobec rozpatrywanego problemu, trzeba zauważyć, że obecnie istotne utrudnienia we wdrażaniu standardów partycypacji w sądownictwie stanowią również zjawiska takie jak „osuwanie się demokracji” (democratic backsliding) i kryzys konstytucyjny. Przyszłość pokaże, czy nieliberalne wizje demokracji są tylko przejściową aberracja, czy

${ }^{43}$ Koczanowicz (2011). 
też może istotnie i trwale przemodelują standardy dotyczące organizacji sądownictwa. Należy przy tym zaakcentować, że wizje te opierają się na wymogu lojalności prawników wobec władzy politycznej i budowaniu wspólnoty wokół tradycyjnych, Schmittowskich rozróżnień typu „my i oni” czy „przyjaciel i wróg”. Z jednej strony w obliczu aktualnych, nieliberalnych tendencji w przeobrażaniu demokracji odważne, proobywatelskie propozycje reformowania wymiaru sprawiedliwości mogą jawić się jako wyraz myślenia życzeniowego lub nierealistyczna utopia. Z drugiej zaś strony propozycje te mają krytyczno-afirmatywny potencjał, dzięki któremu stanowią istotną alternatywę dla minimalistycznych programów reform sądownictwa, sprowadzających się zasadniczo do zmian kadrowo-organizacyjnych.

\section{PODSUMOWANIE}

Reasumując, należy podkreślić, że koncepcja „triady” kompetencji sędziowskich ma szeroki potencjał aplikacyjny. Może ona zostać wykorzystana m.in. do rozwijania teorii lub koncepcji prawa uwzględniających idee partycypacji i dialogu społecznego. Prawnicy posiadają szczególne zdolności zawodowe, dzięki którym, za pośrednictwem określonych instytucji partycypacji społecznej, mogą wzmacniać legitymizację prawa. Źródłem konceptualnej więzi między koncepcja kompetencji sędziowskich a idea partycypacji jest zasygnalizowana na wstępie normatywna wizja porządku demokratycznego. Kompetencje sędziowskie stanowią zespół cech i umiejętności zawodowych oraz szczególną postać zdolności dyskursywno-komunikacyjnych służąca realizacji prawa do uzasadnienia. To ostatnie stanowi zaś metaprawo, na podstawie którego konstruowane sa prawa pozytywno-partycypacyjne rozumiane jako standardy prawne.

Przedstawione rozważania wskazuja, że „triada” kompetencyjna sędziego pozwala spojrzeć na relację między ideałami demokratycznymi a praktyka prawniczą przez pryzmat koncepcji upełnomocnienia obywateli. Warunkiem rzeczywistego upełnomocnienia jest uwzględnianie zasady partycypacji społecznej, której istotę stanowi proliferacja podmiotowości jednostek i ich grup. Krytyczne zaangażowanie prawników w realizację standardów partycypacji polega m.in. na przyjmowaniu kryterium konstytucyjnoprawnego jako racji przemawiajaccej za udzieleniem ochrony prawnej. Koncepcja „triady” kompetencyjnej jest ukierunkowana na poszukiwanie takiej interpretacji prawa, która będzie stanowić wyraz pragmatycznego kompromisu między wartościami leżącymi u podstaw argumentacji przedstawionej przez obywateli. Źródeł uprawomocnienia władzy prawników nad znaczeniem prawa upatruje się przy tym w nowych formach komunikacji sądowej uwzględniajacych idee refleksyjności i sieci.

Kompetencje sędziowskie pełnią następujące funkcje: krytyczna, motywujacca, integracyjna, dynamizująca i emancypacyjną. Owe kompetencje stanowią środki, za pomocą których możliwe jest kooperatywne tworzenie stan- 
dardów prawnych przez ustawiczne kontestowanie określonych instytucji (praktyk i ideałów). Natomiast przyjęcie, że zasada partycypacji społecznej stanowi wstępne założenie stosunków prawnych jest niezbędne dla pełnego zrozumienia jakościowej zmiany w prawie. Zmiana ta polega na stopniowym przechodzeniu od pozytywistycznego paradygmatu prawa ufundowanego na regułach (rules-based) i relacjach hierarchicznych lub rynkowych do paradygmatu partycypacyjnego opartego na zasadach (principles-based) i sieciowej strukturze wymiaru sprawiedliwości ${ }^{44}$.

Postulat refleksyjnego kształtowania kompetencji sędziowskich jest zatem pokłosiem istotnych przeobrażeń, jakie dokonują się w ostatnich latach w relacjach między władzami publicznymi a obywatelami. Powiązanie kompetencji sędziowskich z idea partycypacji jest niezbędne z punktu widzenia legitymizacji judykatywy i ochrony praw pozytywno-partycypacyjnych na forum dialogu społecznego. Teza o potrzebie kształtowania dialogicznej architektury instytucjonalnej w demokracji konstytucyjnej jest przy tym obecna w literaturze juz od dłuższego czasu. Nie ulega wątpliwości, że konieczne jest kontynuowanie refleksji w tym zakresie. Niezbędne wydaje się więc ukierunkowanie dalszej dyskusji na powinności legitymizacyjne prawników wynikające z postulatu partycypacji społecznej i artykułowane w kategoriach kompetencji kształtujących krytyczno-normatywne orientacje aktorów życia prawnego.

Mariola $\dot{Z} a k$

Uniwersytet Warszawski

mariolazak@poczta.fm

https://orcid.org/0000-0003-1349-2246

Azmanova, A. (2018). Relational, structural and systemic forms of power: the 'right to justification' confronting three types of domination. Journal of Political Power 11(1): 68-78.

Banasik, P. (2015). Organizacja wymiaru sprawiedliwości w strukturze sieci publicznej- możliwe interakcje. E-mentor 2(59): 56-64.

Bańkowski, Z. (2009). W przestrzeni sądzenia: sędzia i niepokój spotkania. Tłum. M. Pichlak, [w:] P. Kaczmarek (red.), Z zagadnień teorii i filozofii prawa. Lokalny i uniwersalny charakter interpretacji prawniczej. Wrocław: 167-186.

Benhabib, S. (2011). Dignity in Adversity: Human Rights in Troubled Times. Cambridge.

Burdziej, S. (2017). Sprawiedliwość i prawomocność. O społecznej legitymizacji władzy sądowniczej. Toruń.

Cern, K.M. (2014). On the intrinsic correlation between public legitimation of democratic law and discursive competencies of citizens. Filozofia Publiczna i Edukacja Demokratyczna 3(2): $57-67$.

Cohen, J. (1989). Deliberation and democratic legitimacy, [w:] A. Hamlin, P. Pettit (eds.), The Good Polity: Normative Analysis of the State. Oxford: 17-34.

Forst, R. (2011). The Right to Justification: Elements of a Constructivist Theory of Justice. Transl. J. Flynn. New York.

Forst, R. (2013). Justification and Critique: Towards a Critical Theory of Politics. Transl. C. Cronin. Cambridge.

Forst, R. (2017a). What's critical about a critical theory of justice? [w:] B. Bargu, Ch. Bottici (eds.), Feminism, Capitalism, and Critique: Essays in Honor of Nancy Fraser. Cham: 225-242.

${ }^{44}$ Por. Banasik (2015): 56-64. 
Forst, R. (2017b). Normativity and Power. Analyzing Social Orders of Justification. Transl. C. Cronin. Oxford.

Grygieńć, J. (2016). Wspólnota responsywna, czyli jaka? Komunitaryzm wobec problemu partycypacji politycznej. Prakseologia 158(2): 75-97.

Habermas, J. (2005). Faktyczność i obowiązywanie. Teoria dyskursu wobec zagadnień prawa i demokratycznego państwa prawnego. Tłum. A. Romaniuk, R. Marszałek. Warszawa.

Izdebski, H. (2001). Geneza i ewolucja pojęcia „państwa prawnego”. Studia Iuridica 39: 28-33.

Izdebski, H. (2006). Jednostka wobec rządów prawa i państwa prawnego, [w:] M. Wyrzykowski (red.), Prawa stają się prawem. Status jednostki a tendencje rozwojowe prawa. Warszawa: $149-156$.

Izdebski, H. (2012). Doktryny polityczno-prawne. Fundamenty współczesnych państw. Warszawa.

Juchacz, P.W. (2006). Demokracja, deliberacja, partycypacja. Szkice z teorii demokracji ateńskiej i współczesnej. Poznań.

Juchacz, P.W. (2015). Deliberatywna filozofia publiczna. Analiza instytucji wysłuchania publicznego w Sejmie Rzeczpospolitej Polskiej z perspektywy systemowego podejścia do demokracji deliberatywnej. Poznań.

Kaleta, K.J. (2018a). Władza konstytuująca jako przedmiot badań nauk prawnych. Filozofia Publiczna i Edukacja Demokratyczna 7(1): 41-62.

Kaleta, K.J. (2018b). Legitymizacja sądownictwa konstytucyjnego w świetle teorii demokracji. Państwo i Prawo 95(5): 3-21.

Koczanowicz, L. (2011). Lęk nowoczesny. Eseje o demokracji i jej adwersarzach. Kraków.

Koncewicz, T.T. (2016). Sądowa sprawiedliwość proceduralna w prawie europejskim. Gdańskie Studia Prawnicze 35: 173-254.

Łętowska, E. (2002). Kilka uwag o praktyce wykładni. Kwartalnik Prawa Prywatnego 11(1): $27-54$.

Łętowska, E. (2003). Boska sztuka interpretacji, [w:] A. Łopatka, B. Kunicka-Michalska, S. Kiewlicz (red.), Prawo, społeczeństwo, jednostka. Księga jubileuszowa dedykowana Profesorowi Leszkowi Kubickiemu. Warszawa: 25-35.

Mansbridge, J.J. (2018). Participation, Deliberation, Legitimate Coercion. Ed. M.S. Williams. Abingdon-New York.

Nussbaum, M.C. (2011). Creating Capabilities. The Human Development Approach. CambridgeLondon.

Pateman, C. (1970). Participation and Democratic Theory. Cambridge.

Renault, E. (2016). Critical Theory and Processual Social Ontology. Journal of Social Ontology 2(1): $17-32$.

Romanowicz, M. (2014). Argument z autorytetu w dyskursie sądowym - próba wyjaśnienia, [w:] T. Stawecki, J. Winczorek (red.), Wykładnia konstytucji. Inspiracje, teorie, argumenty. Warszawa: 483-515.

Sen, A. (1985). Commodities and Capabilities. Amsterdam.

Skrzypiński, D. (2014). Odpowiedzialność sędziów w świetle zjawiska judykalizacji polityki. Wrocławskie Studia Politologiczne 17: 53-64.

Skuczyński, P. (2019). Aktywizm sędziowski a etyka sędziowska w Polsce. Uwagi w stulecie niepodległości, [w:] Ł. Pisarczyk (red.), Między tradycją i nowoczesnością. Prawo polskie w 100-lecie odzyskania niepodległości. Warszawa: 359-382.

Smolak, M. (2007). Niezawisłość sędziowska a wykładnia funkcjonalna. Ruch Prawniczy, Ekonomiczny i Socjologiczny 69(4): 27-34.

Smolak, M. (2019). The Culture of Justification and Public Reason: Comments on the Motion of Members of the Polish Parliament to the Constitutional Tribunal. Archiwum Filozofii Prawa i Filozofii Społecznej 20(2): 29-38.

Uziębło, P. (2009). Demokracja partycypacyjna. Wprowadzenie. Gdańsk.

Wojtczak, S. (2017). The Metaphorical Engine of Legal Reasoning and Legal Interpretation. Warszawa.

Zabdyr-Jamróz, M. (2014). Decyzyjny paradoks deliberacji. Perspektywy zastosowań różnych technik demokracji deliberatywnej, [w:] Ł. Scheffs (red.), Społeczno-polityczne wyzwania współczesności. Toruń: 89-102.

Zienkiewicz, A. (2018). The Lawyer Personality. Właściwości personalne prawnika a wykonywanie roli zawodowej. Archiwum Filozofii Prawa i Filozofii Społecznej 16(1): 94-102. 


\section{JUDGES' PROFESSIONAL COMPETENCIES AND THE INSTITUTIONALIZATION OF SOCIAL PARTICIPATION IN THE JUDICIAL SYSTEM}

\section{S u m m a r y}

The purpose of the article is to determine the relationship between judges' professional competencies as special kind of capabilities and the development of institutions of civic participation, as well as the protection of third-generation, public positive-participatory rights. This paper is divided into two parts. The first part presents the elements of so-called judge's competence 'triad' to demonstrate that reflexive competence formation is a necessary condition for full participation in contemporary legal practice, and for developing the ideal of inclusive community. Next, an attempt is made to verify the thesis that participatory democracy institutions create optimal conditions for the use of judges' competencies in the processes of citizens' empowerment. The capabilities approach has been most widely adopted in deliberative democracy theory. Therefore, the philosophical and legal justification of the relationship between the professional competencies of lawyers and the idea of social participation should be sought on the basis of discourse theory.

Keywords: judges' professional competencies; capabilities approach; civic participation; empowerment; deliberative democracy; right to justification; public legitimacy 
